Relations industrielles

Industrial Relations

\title{
Handbook of Work Stress edited by Julian BARLING, E. Kevin KelloWAY and Michael R. Frone, Thousand Oaks, Calif.: Sage Publications, 2005, 710 pp., ISBN 0-7619-2949-5.
}

\section{Ronald J. Burke}

Volume 60, numéro 2, printemps 2005

URI : https://id.erudit.org/iderudit/011734ar

DOI : https://doi.org/10.7202/011734ar

Aller au sommaire du numéro

Éditeur(s)

Département des relations industrielles de l'Université Laval

ISSN

0034-379X (imprimé)

1703-8138 (numérique)

Découvrir la revue

Citer ce compte rendu

Burke, R. J. (2005). Compte rendu de [Handbook of Work Stress edited by Julian BARLing, E. Kevin Kelloway and Michael R. Frone, Thousand Oaks, Calif.: Sage Publications, 2005, 710 pp., ISBN 0-7619-2949-5.] Relations industrielles / Industrial Relations, 60(2), 390-392.

https://doi.org/10.7202/011734ar d'utilisation que vous pouvez consulter en ligne. 
qui se défait, on ne peut faire fi de la prédominance de l'ordre marchand et de ses conséquences sur la déstructuration de la société.

D'autre part, une question fondamentale n'a pas été abordée : la place de l'État dans l'économie sociale? Le projet de l'économie solidaire propose une alternative à la logique concurrentielle (marché) et à la logique de redistribution. Mais la redistribution classique par la protection sociale doit-elle pour autant disparaître ? La démocratisation de certaines pratiques sociales ne doit pas se traduire par une absence de l'État qui reviendrait à une privatisation. Ainsi, la réforme du système de protection sociale nécessiterat-elle une redéfinition du rôle de l'État. Les pouvoirs publics doivent en effet aider au développement de l'économie sociale tout en apprenant à travailler avec elle. L'État doit donc garder un rôle dans la définition de la politique de santé. Malgré ces quelques critiques, cet ouvrage permettra d'alimenter le débat sur la réforme des politiques sociales.

Jean-Paul Domin

Université de Reims

Champagne-Ardenne

\section{Handbook of Work Stress}

edited by Julian Barling, E. Kevin Kelloway and Michael R. Frone, Thousand Oaks, Calif.: Sage Publications, 2005, 710 pp., ISBN 0-76192949-5.

Publishers today, particularly Sage, seem to be publishing more Handbooks. The Handbook of Work Stress reflects this trend. This collection comprises 27 chapters divided into four parts. The 27 chapters include four brief chapters at the start of each part that set the stage for each part, providing short summaries of the chapters that follow; 23 chapters provide new content.

I was surprised that the Handbook did not provide information about the collection's purposes and themes or who the intended target audience was, from the outset. The back cover did indicate that the collection focused primarily on identifying the various sources of work stress across different contexts and individuals and was essential reading for researchers. But the collection is more than this. It may be that a handbook's objectives are widely understood but I think an early positioning of the collection would have been useful. A statement of purpose might indicate the work stress content to be included and why, the work stress content excluded and why and how the content could be useful in creating healthier workplaces.

Part I, Sources of work stress, is the largest part (396 pages) consisting of 15 chapters. Part II, Special populations (142 pages) consists of 6 chapters. Part III, Consequences of work stress (55 pages) contains 3 chapters. Finally, Part IV, Interventions (44 pages) consists of 3 chapters.

The chapters in Part I review 14 different sources of work stress. Some of these have been studied for a long time (e.g., role stress, work schedules, workfamily conflict) while others have only recently begun to receive attention (e.g., workplace aggression, terrorism). The remaining chapters address organization justice, poor leadership, harassment and discrimination, the physical work environment, workplace safety, economic stressors, technology, industrial relations, and organizational politics. It is not clear why these stressors were included and not others or whether there was a particular order to the sequencing 
of the chapters. Did they move from the most heavily and longest researched to the less researched and more recent stressors? It was indicated that each chapter would review content relevant to its specific stressors, identify methodological issues and suggest future research directions. Some authors did this while other authors did not. Those chapters that include policy and intervention suggestions were particularly helpful. There was also some content overlap between the various sources of work stress, for example, workplace aggression and sexual harassment. In addition, almost all of these chapters include individual difference or personal disposition variables as well as the same stress outcomes. This is likely inevitable given the structure of the collection.

Five special populations are considered in Part II as defined by gender, age (younger and older), employment status (full-time, part-time, contingent) and culture or national origin. The editors suggest that the stress process may be different in groups defined by demographic differences. They note that although the generic stress model may be the same for all groups, particular sub-groups may experience different stressors, the same stressors but to a different degree, the same stressors but report different reactions to them, and that some stress outcomes may be more important for some sub-groups than others. A consideration of these special populations makes it possible to test the boundaries of current stress theories. While all this may be true, it is generally left up to the reader to draw these conclusions.

The two chapters in Part III review consequences of work stress considering both individual and organizational consequences at psychological, physical and behavioural levels (Chapter 24, Jex and Crossley) and mental health (Chapter 23, Warr). Warr correctly notes the importance of including positive indicators of well-being in future work stress research.

Part IV, Intervention, includes two chapters, one targeting individuals, the other addressing organizations, using the traditional breakdown of primary, secondary and tertiary levels of intervention As the authors of both of these chapters note, effective stress reduction efforts must address both individuals and their behaviours and the work environment.

The Handbook or Work Stress has considerable strengths. The chapters are well written and the relevant literature identified, summarized and appropriately integrated. Readers interested in specific work stress content can readily access the key contributions. As such, it provides an outstanding resource for academic researchers. I was disappointed, though, that stand-alone chapters were not devoted to burnout, coping, individual difference and personal predispositions such as coronaryprone behaviour and work addiction, the effects of work stress on children and families, and policy initiatives at the societal level to address work stress issues. In addition, this collection, like many of the other work stress collections, has a decidedly North American emphasis. While it includes references to the contribution of stress researchers from a number of different countries, the potentially unique perspective offered by stress researchers from these countries is not available to us.

The editors and some contributors note the large gap between research evidence and our understanding of the work stress and health relationship and our efforts to do something about this. Stress research has been ongoing for over 40 years; the acknowledged costs of work stress to individuals, families, organizations and society at large are staggering. While this collection highlights the gap and the costs, and some authors deal with interventions and policy implications, much more needs to be done here. 
Fourteen chapters on sources of work stress and two chapters on intervention are an indication of this and may well reflect the current state of the field This is not so much a comment on this Handbook as it stands, as on what the
Handbook might have been. We are still waiting for the Handbook of Work Stress Management and Prevention.

RONALD J. BURKE York University

\section{La gestion environnementale et la norme ISO 14001}

par Corinne Gendron, Montréal : Presses de l'Université de Montréal, 2004, 347 p., ISBN 2-7606-1809-9.

La gestion environnementale représente aujourd'hui un enjeu majeur pour les entreprises, en particulier dans l'industrie où les pressions externes et les contraintes réglementaires ne sauraient être négligées sans hypothéquer la légitimité, voire la survie des activités économiques. Sociologue de formation et professeur à l'Université du Québec à Montréal, Corinne Gendron entend proposer dans cet ouvrage un tour d'horizon des principales facettes du management vert des entreprises, à partir notamment de la structure et des recommandations de la norme ISO 14001. Lancée en 1996, cette norme s'est en effet imposée comme le système de gestion environnementale de référence, au même titre que le référentiel ISO 9001 dans le domaine de la qualité. L'ouvrage s'articule autour de trois parties qui abordent des thèmes classiques sur la question.

La première partie s'attache à exposer les principaux enjeux environnementaux et les défis qu'ils soulèvent pour la gestion des entreprises. Dans le premier chapitre, quelques problèmes environnementaux majeurs, comme le réchauffement climatique, la déforestation, la désertification, l'urbanisation ou encore la croissance démographique sont abordés de façon très succincte. Le concept de développement durable et les principaux instruments des politiques publiques pour l'environnement sont également évoqués en des termes très généraux. Le second chapitre décrit les motivations des actions environnementales et les stratégies plus ou moins engagées dans ce domaine en reprenant ici encore des thèmes et des idées largement débattues dans la littérature.

La deuxième partie de l'ouvrage est centrée sur le système ISO 14001. Après avoir rappelé ce que sont les systèmes de gestion environnementale et avoir donné quelques exemples à ce sujet, l'auteure décrit de façon analytique et séquentielle les principales composantes de la norme : politique environnementale, planification, mise en œuvre et fonctionnement, contrôle et actions correctives, revue de direction. Ces différents thèmes sont repris, plus en détails, mais de façon toujours très descriptive, dans le chapitre 4 . Le chapitre 5 s'attache à montrer les enjeux de la certification ISO 14001 en reprenant des données aisément disponibles sur le sujet : nombre de certifications dans le monde, aspects commerciaux, etc. Le dernier chapitre de cette partie traite d'un sujet se prêtant a priori à des développements plus originaux et auxquels l'auteure, de formation juridique, n'est certainement pas insensible : la norme ISO 14001 et la loi. Ce sujet est cependant abordé de façon assez générale et simplifiée à partir de quelques thèmes bien balisés : les prescriptions de la norme par rapport aux exigences réglementaires, les infractions environnementales, la défense de diligence raisonnable, la responsabilité juridique.

La troisième et dernière partie de l'ouvrage traite des outils de la gestion environnementale. L'auteure reprend en fait trois thèmes déjà abordés dans les chapitres précédents à travers l'examen 